\title{
The Leadership of Pancasila in Education: Foundation for Strengthening Student Characters in the Industrial Revolution Era 4.0
}

\author{
Hasan Argadinata \\ Department of Educational Administration \\ Universitas Negeri Malang, Indonesia \\ hasanargadinata@gmail.com
}

\author{
Imam Gunawan \\ Department of Educational Administration \\ Universitas Negeri Malang, Indonesia \\ imam.gunawan.fip@um.ac.id
}

\begin{abstract}
The industrial revolution is currently entering an increasingly advanced era with the support of internet use and digitalization. The 4.0 industrial revolution that is currently developing changes the records of all fields, including the world of education. The incessant flow of information that occurs at this time requires individuals to be able to organize into useful data. The information obtained can change the mindset of individuals. Strengthening character and identity is important so that individuals do not lose their identity. The role and position of educational leadership at this time must also be in line with these developments. Because with these developments, interactions and communication that occur in schools will change, both in terms of patterns and communication tools. The existence of technological developments will affect the principal's interaction pattern as an educational leader with all school residents (teachers, staff, and students). For the principal's leadership behaviors and teacher behavior and student behavior to remain in a good corridor, the Pancasila leadership is important and becomes the basis for behaving.
\end{abstract}

Keyword: the leadership of Pancasila, principalship, industrial revolution era 4.0

\section{INTRODUCTION}

The rapid flow of information supported by the increasingly rapid use of the internet today is changing the way people think and think. Information technology is now a lifestyle that can affect the individual behavior of its users. The education sector must not be left behind with technological developments.

Therefore, the education sector must be able to transform positive values to students so that they can use the information technology wisely and can help the learning process. This can be realized if the education leader realizes that the current generation of students (students) is generation $\mathrm{Z}$ or commonly called millennial generation who tend to use very high information technology.

Every breath of millennial generation today is always related to and related to technology. The millennial generation is a generation that has its uniqueness, such as cannot be separated from information technology, the desire that is fast, high obsession, and has an individual nature.

Therefore, all components and educational tools must be optimized in such a way to provide provisions for students to live in a real society (real, not citizens). This has also been warned by Unesco [1] who stressed that the need to make people aware of the important role of education for young people. The principal as an educational leader in the school is a key person who can strengthen the character of his students, with the support of the teachers.

It is undeniable that the wave of information technology can change the mindset, behavior, and direction of students' views [2], and it is also possible to change the character of students. Therefore, there is a need for the principal's leadership role and the teacher's inspiration to strengthen the character of students during the changing times. Strengthening students' ethics and character must be integrated with teaching activities carried out by teachers [3], [4], [5]. Student learning behavior is influenced by the teaching behavior of the teacher, while the teaching behavior of the teacher is influenced by the behavior of the principal [6]. Based on these arguments, it can be seen that the principal's leadership position is a determinant of student success.

Pancasila as the basis of the state has values that must be heeded in the delivery of education. Pancasila becomes the breath and identity of every citizen in every aspect of life. It should and should be the principal as an educational leader in the school also practices the values of Pancasila. The Pancasila leadership becomes an educational leadership model that must be applied by the school principal [7], [8], and can be a filter for behaviors and views from outside, especially behavior and views originating from foreign ideologies (especially ideologies that are not in harmony with Pancasila which can disrupt the Unitary Republic of Indonesia). Schools must be at the forefront in strengthening the national character of students.

This paper will explore the Pancasila Leadership model implemented by school principals to strengthen the strong character of students, especially in the industrial era 4.0. The urgency of the discussion is that in addition to students having the character that is demanded to have in the industrial era 4.0, students must also have a strong national character, so that they do not forget their identity as Indonesian people. The school component that has the task to realize that is the principal and teachers. Principals with their leadership characteristics must be able to form students who have strong character and ethics [4], while teachers through their learning activities must inspire national life and strong national character.

\section{THE LEADERSHIP OF PANCASILA}

Pancasila as the nation's philosophy contains noble values which form the basis of Indonesian people's behavior [7]. Therefore, the position of the Pancasila is clear and firm. Pancasila as an ideology of the nation has three integrated elements, namely: knowledge, beliefs, and actions [9], [10]. Knowledge is a basic element of human cognitive. Based on the knowledge he obtained, it will create a belief, which is a belief that will cause seriousness to behave. Furthermore, knowledge and belief 
will become actions, when they have become real behavior, as a result of the existence of that belief. Pancasila will be an indicator of a person's behavior in people's lives. The attributes of the Pancasila leadership are transcendence, humanization, diversity, liberation, and justice [12].

The ideal leader traits that are in harmony with the values of Pancasila are: (1) having high piety towards God; (2) upholding human values; (3) able to unite in the midst of differences; (4) prioritizing consensus agreement; and (5) bringing justice to justice [13]. If examined further, then the five characteristics of the Pancasila leadership must be tangible in action so that the community trust and become the identity of every citizen.

Clean, transparent, and professional are three important elements that accompany the attributes of Pancasila leadership [14]. So that the attributes of the Pancasila leadership derived from the values of the Pancasila precepts can be manifested in school life [7]. Pancasila will become an awareness of deeds [9].

\section{STUDENT CHARACTER VALUES}

The next question is what character must be strengthened in students to face change? The character is a provision for students to be able to adapt to changes. If referring to the definition of education in Law Number 20 Year 2003 concerning the National Education System, the characters strengthened in students are spiritual strength, self-control, personality, intelligence, and noble character [15].

Besides, the characters that must also be developed are good words; make good use of time; reward or appreciate the work with prizes; serving people well; and able to give peace to people [4]. Sarros and Cooper [16] mention there are five-character attributes, namely: courage, enthusiasm, wisdom, competence, and selfdiscipline. Character is an important thing that must be owned by every individual. How students behave towards a social phenomenon that occurs will determine the character of these students.

Although the characters are part of the affective domain, the reasoning and thinking the power of students will also affect the formation of character. Every student needs to be made aware that he has a moral responsibility to live in harmony, harmony and balance with others. Also, he has a moral responsibility to always uphold the character values that are manifested in his behavior [4].

\section{VALUE OF CHARACTER OF THE}

\section{INDUSTRIAL REVOLUTION ERA 4.0}

Each era will demand a different character following the conditions of the development. The era of the industrial revolution 4.0 which combines physical, digital and biological technology [16], also requires several characters so that people can adapt to these changes. The characters that must be possessed during the industrial revolution era 4.0 include integrity, tenacity, analytics, critical, creative, innovative, and hard work.

Although the main characteristic of the industrial revolution era 4.0 is the use of the internet and digitalization with an automated work system, if the user does not have that character, then he will become a human resource (HR) who does not have character. Also, the 4.0 industrial revolution has characteristics, namely: internet use; automation of data exchange and communication processes; prioritize services that have added value; the existence of machine-human interaction; high adaptation; production optimization; and digitization [16].

The role of humans in any era will remain dominant and determine the landscape of the changing times. Competence and capability, as well as one's character, will become an integrated unit in shaping one's work ethic. Students as a generation of the nation, in addition to being equipped with mastery of technology, must also be equipped with strong characters as well.

The use of information technology is expected to be utilized as much as possible for the benefit of the people. This is in line with [17] which states that education has the task of directing students from individual thoughts towards devotional thoughts to the community.

\section{THE PANCASILA LEADERSHIP MODEL IN STRENGTHENING THE CHARACTER OF STUDENTS IN THE INDUSTRIAL REVOLUTION ERA 4.0}

Pancasila is a source of ethics in the perspective of the concept and professional work of human resources [16], including in this case human resources in education, namely the principal, teachers, and staff. The four main focuses of character education priority are leadership, values, good governance, and nationalism [18].

Therefore, educational institutions have the task of preparing their students well, by developing concrete and actionable action plans for the transition to an economic and social education system that can accommodate innovative change [19], [20].

When referring to the theoretical study as described, then a Pancasila leadership model can be described in strengthening the character of students in the era of the industrial revolution 4.0 as illustrated as in Figure 1. If referring to Figure 1, it can be seen that there is a relationship of influence in the process of shaping the character of students so that they can live in the era of the industrial revolution 4.0.

Students will have a stronger character by emulating the Pancasila leadership qualities displayed by the principal, namely the characteristics of matters relating to transcendence, humanization, diversity, liberation, and justice. The attributes of the Pancasila leadership will be holistic with the support of character values that have been reduced in character education, which includes religious-spiritual strength, self-control, personality, intelligence, and noble character.

Finally, supported by these variables, students are expected to have the character values demanded in the era of the industrial revolution 4.0, namely: integrity, tenacity, analytic, critical, creative, innovative, forward, service, hard work, high adaptation, digitalization, competence, capabilities, productivity, and machinehuman interaction. 


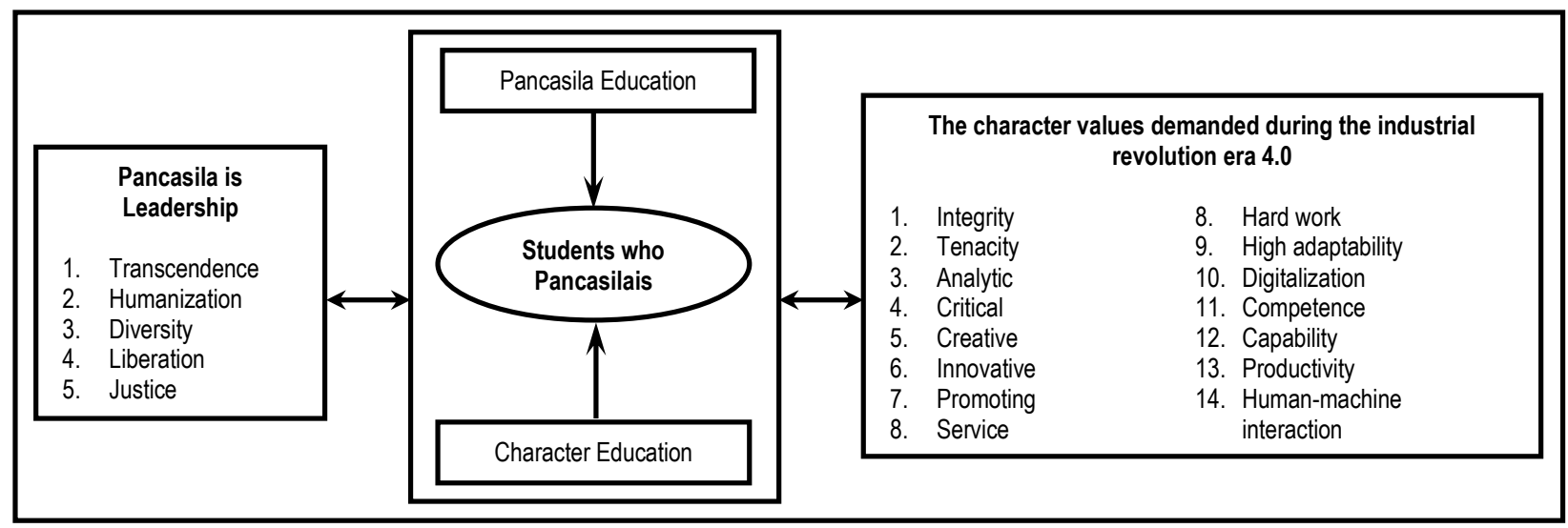

Figure 1

The Pancasila Leadership Model in Strengthening the Character of Students in the Era of the Industrial Revolution 4.0

\section{CONCLUSION}

If referring to the explanation above, it can be seen how important the leadership of the school based on the Pancasila leadership can strengthen the character of students in the industrial revolution era 4.0. The principal has a strategic role related to character education, through the leadership that he applies. The concrete manifestation of the Pancasila leadership applied by the school principal is the collective awareness of all school members to practice the noble values of the Pancasila precepts in organizing education in their schools.

\section{REFERENCES}

[1] Unesco. 1995. Training Materials for Continuing Education Personnel: Income Generating Programmers. Bangkok: Unesco, Principal Regional Office for Asia and the Pasific.

[2] Hardika, Aisyah, E. N., Widianto, E., and Gunawan, I. 2018. Transformasi Makna Belajar Generasi Milenial: Studi Fenomenologi tentang Mindset, Perilaku, dan Capaian Belajar Mahasiswa dalam Perspektif Life Base Learning. Research report. Malang: LP2M Universitas Negeri Malang.

[3] Kalaitzidis, E., and Schmitz, K. 2012. A Study of An Ethics Education Topic for Undergraduate Nursing Students. Nurse Education Today, 32(1), 111-115.

[4] Sultoni, Gunawan, I., and Sari, D. N. 2018. Pengaruh Etika Profesional terhadap Pembentukan Karakter Mahasiswa. JAMP: Jurnal Adminitrasi dan Manajemen Pendidikan, 1(3), 279-283.

[5] Jagger, S., and Volkman, R. 2014. Helping Students to See for Themselves that Ethics Matters. The International Journal of Management Education, 12(2), 177-185.

[6] Alfonso, R. J., Firth, G. R., and Neville, R. F. 1981. Instructional Supervision: A Behavioral System. Boston: Allyn and Bacon, Inc.

[7] Gunawan, I. 2016a. Merevitalisasi Kepemimpinan Pancasila dalam Bidang Pendidikan. Proceedings National Seminar: Penguatan Manajemen Pendidikan di Era Kompetisi Global, Jurusan Administrasi Pendidikan Universitas Negeri Malang, 12 March, p. 67-84.

[8] Gunawan, I. 2016b. Perspectives of Pancasila: Leadership Education's Values and Ethics. Proceeding International Conferences on Education and Training, $2^{\text {nd }}$ ICET Theme:
Improving the Quality of Education and Training Through Strengthening Networking, 4 - 6 November, p. 435-438.

[9] Latif, Y. 2014. Mata Air Keteladanan: Pancasila dalam Perbuatan. Jakarta: Mizan.

[10] Kaelan. 2017. Negara Kebangsaan Pancasila. Yogyakarta: Paradigma.

[11] Gunawan, I. 2012. Mengembangkan Karakter Bangsa Berdasarkan Kearifan Lokal. Proceedings National Seminar: Meretas Sekolah Humanis untuk Mendesain Siswa Sekolah Dasar yang Cerdas dan Berkarakter, PGSD FKIP Universitas Muhammadiyah Surakarta, 6 May, p. 67-79.

[12] Sutrisno, T. 2013. Pokok-pokok Pikiran Sosok Pemimpin Nasional yang Ideal. Majalah TANNAS, Edisi 95.

[13] Purnama, B. T. 2010. Mengembalikan Relevansi Pancasila: Menangkal Terorisme, Komunisme, dan Neoimperialisme. Retrieved May 2, 2019, from http://www.dpr.go.id.

[14] Law Number 20 Year 2003 concerning the National Education System. 2015. Jakarta: Sinar Grafika.

[15] Dhakiri, M. H. 2018. Era Revolusi Industri 4.0 harus Diantisipasi Perguruan Tinggi. Retrieved May 2, 2019, from http://www.tribunnews.com/kilaskementerian/2018/02/11/era-revolusi-industri-40-harusdiantisipasi-perguruan-tinggi.

[16] Sarros, J. C., and Cooper, B. K. 2006. Building Character: A Leadership Essential. Journal of Business and Psychology, 21(1), 1-22.

[17] Prasetyo, T. W. B. 2018. Pancasila sebagai Sumber Etika dalam Era Revolusi Industri. Retrieved May 2, 2019, from http://jogja.tribunnews.com/2018/05/30/pancasila-sebagaisumber-etika-dalam-era-revolusi-industri.

[18] Dewantara, K. H. 2011. Pendidikan. Yogyakarta: Yayasan Persatuan Taman Siswa.

[19] Kemristekdikti. 2017. Memandang Revolusi Industri dan Dialog Pendidikan Karakter di Perguruan Tinggi Indonesia. Jakarta: Majelis Pendidikan, Dewan Pendidikan Tinggi, Kementerian Riset, Teknologi dan Pendidikan Tinggi.

[20] Sung, T. K. 2018. Industry 4.0: A Korea Perspective. Technological Forecasting and Social Change, 132, 4045 . 